\title{
Influence of sugarcane (Saccharum officinarum) straw on weed germination control
}

\section{La influencia del manejo de residuo agrícola de cosecha en el control de los flujos de germinación de malezas en caña de azúcar (Saccharum officinarum)}

Paulo Vinicius da Silva ${ }^{1}$, Henrique Rodrigues Milagres Viana ${ }^{2}$, Patricia Andrea Monquero ${ }^{3}$, Nagila Moraes Ribeiro ${ }^{4}$, Wilson Pereira Neto ${ }^{5}$, Estela Maris Inacio ${ }^{6}$, Pedro Jacob Christoffoleti ${ }^{7}$, Roque de Carvalho Dias $^{8}$

Originales: Recepción: 09/07/2020 - Aceptación: 08/04/2021

\begin{abstract}
This research studied the effectiveness of herbicide treatments in weed control and during different periods of emergence, when applied to varying amounts of straw. The experiment was conducted in a greenhouse with pre-emergent herbicides: amicarbazone, metribuzin, indaziflam, isoxaflutole, amicarbazone + indaziflam, metribuzin + indaziflam, and isoxaflutole + indaziflam, against three species (Sorghum halepense, Rottboellia exaltata, and Mucuna aterrima). The experimental design was completely randomized in a $5 \times 4$ factorial scheme, with five amounts of straw $(0,1,2,3$, and $5 \mathrm{t} / \mathrm{ha})$ and four periods of weed emergence $(0,30,60$, and 90 days after treatments). The residual control of indaziflam was influenced by the amount of straw. Metribuzin presented a low residual control, while isoxaflutole was not affected by the amount of straw. Amicarbazone offered residual control for Mucuna aterrima. The association between indaziflam + isoxaflutole displayed a suitable residual control against Sorghum halepense and Rottboellia exaltata. The association of indaziflam + metribuzin adequately controlled Mucuna aterrima and Sorghum halepense. herbicide physical-chemical characteristics can influence their performance, and the association of products may increase residual and weed spectrum control.
\end{abstract}

\section{Keywords}

Leaching • germination-asynchronous $\bullet$ residual $\bullet$ wet season

1 Univerdade Federal da Grande Dourados UFGD. Faculdade de Ciências Agrarias FCA.

2 Universidade de São Paulo. Escola Superior de Agricultura "Luiz de Queiroz".

3 Universidade Federal de São Carlos/UFSCar. Centro de Ciências Agrárias/CCA

4 Universidade Estadual Paulista Júlio de Mesquita Filho. Faculdade de Ciências Agrárias e Veterinárias. Campus Jaboticabal (FCAV/Unesp)

5 Universidade de São Paulo. Escola Superior de Agricultura "Luiz de Queiroz".

6 Universidade Estadual de Ponta Grossa. UEPG

7 Universidade de São Paulo. Escola Superior de Agricultura "Luiz de Queiroz".

8 Universidade Estadual Paulista Júlio de Mesquita Filho. Campus de Botucatu Faculdade de Ciências Agronômicas. 


\section{RESUMEN}

El objetivo de este trabajo fue estudiar la efectividad de los tratamientos con herbicidas en el control de malezas en distintos periodos de emergencia aplicados en diferentes cantidades de residuo agrícola de cosecha. El experimento fue conducido en invernadero con los herbicidas pre-emergentes: amicarbazone, metribuzin, indaziflam, isoxaflutole, amicarbazone + indaziflam metribuzin + indaziflam) y isoxaflutole + indaziflam, en el control de tres especies (Sorghum halepense, Rottboellia exaltata y Mucuna aterrima). El diseño experimental fue completamente aleatorio en esquema factorial $5 \times 4$, con cinco cantidades de paja $(0,1,2,3$ y 5 t / ha) y cuatro periodos de emergencia de malas hierbas $(0 ; 30 ; 60$ y 90 días después de la aplicación de los tratamientos). El indaziflam tuvo su residual influenciado por la cantidad de residuo agrícola de cosecha. El metribuzin presentó un residuo bajo, mientras que el Isoxaflutole no fue afectado por la cantidad de paja. Amicarbazone ofreció control residual para Mucuna aterrima. La asociación indaziflam + isoxaflutole presentó residual adecuado para el control de Sorghum halepense y Rottboellia exaltata. La asociación de indaziflam + metribuzin presentó un control adecuado de Mucuna aterrima y Sorghum halepense. Las características físico-químicas de los herbicidas pueden influir en su desempeño, y la asociación de productos puede aumentar el espectro de control de malas hierbas y el residual.

\section{Palabras claves}

Lixiviación • germinación asincrónica • residual • estación lluviosa

\section{INTRODUCTION}

In Brazil, cane fields harvested without earlier burning, were found to yield about 10 to $30 \mathrm{t} / \mathrm{ha}$ of straw, usable for electricity cogeneration, adding value in the sugar and alcohol agroindustry (11). Faced with this possibility, several mills have started to collect and exploit this material resulting in about 0 to $10 \mathrm{t} /$ ha of remaining straw on the soil surface (11).

This partial or total removal of remaining sugarcane straw from the soil surface alters weeds dynamics in sugarcane fields. Concenço et al. (2017) observed that, in Brazil, areas cultivated with sugarcane where cane straw is removed from the crop lines and in-between lines, were considerably more infested with weeds than areas not harvested in the second year of cultivation. Weed species composition also changed, with eudicot weeds such as Euphorbia heterophylla in the line-up and standard areas. Straw removal caused the emergence of Commelina benghalensis, Brachiaria plantaginea, Digitaria insularis, and Digitaria Horizontalis, species, until then, absent in most areas. In other words, straw line-up did not eliminate eudicots infestation and even caused an increase in the outbreak of monocot plants, allowing the composition of a mixed flora.

Therefore, areas that have recently started to completely remove sugarcane straw after harvesting, now present an infesting flora, with hard to control monocotyledonous specieslike Sorghum halepense and Rottboellia exaltata, $(7,14)$. These weed species have small seeds, with rapid germination and quick field colonization (13). These monocot weeds were found in addition to other often reported species in mechanically harvested cane fields, such as Mucuna aterrima (9).

This heterogeneous composition of the infesting flora follows three main causes: (1) The uneven distribution of straw on the soil surface; (2) Years of cultivation in a system without straw burning or its removal, favouring the establishment and high density of weed seeds like Mucuna aterrima in the soil seed bank $(8,17)$. Sugarcane straw on the soil surface may constitute a physical barrier to the application of herbicides with exclusive or preferential soil action. The straw intercepts and retains the herbicides, that become more susceptible to volatilization and/or photolysis before reaching the soil where they are expected to have an effective action (6).

Therefore, finding efficient herbicides against monocot and eudicot weeds, while selective for sugarcane has become necessary. Among these species, some plants are even more difficult to control, such as Sorghum halepense, Rottboellia exaltata, and Mucuna aterrima $(7,9,13,14)$. 
Among available options for weed control in sugarcane crops, amicarbazone (photosystem II), metribuzin (photosystem II), isoxaflutole (IFT), and indaziflam can be used isolated and/or associated (19). This experiment had the objective of studying the effectiveness of herbicide treatments in weed control, during different periods of emergence and when applied to different amounts of straw.

\section{MATERIALS AND METHODS}

The experiment was conducted in a greenhouse in 2016 and repeated in 2017. The experimental design was completely randomized, in a $5 \times 4$ factorial scheme, with four replications, five amounts of straw $(0,1,2,3$, and $5 \mathrm{t} / \mathrm{ha})$ and four periods of weed emergence $(0,30,60$, and 90 days after treatments (DAT)), along with a control without herbicide application.

This factorial scheme was adopted in isolation for each of the seven herbicide treatments (amicarbazone, metribuzin, indaziflam, isoxaflutole, amicarbazone + indaziflam, metribuzin + indaziflam, and isoxaflutole + indaziflam) and three weed species (Sorghum halepense, Rottboellia exaltata, and Mucuna aterrima), meaning that herbicides did not take part of the statistical factors. The experimental units were composed of $20 \mathrm{~L}$ polyethylene pots.

Each weed emergence period represented a flush of seedlings of the germinating species, after? one single sowing, in each period. That is, for each pot, weeds were sown at a single point in time, provoking one germination flush $(0,30,60$, and 90 DAT) causing minimum soil rotation and avoiding moving the herbicide out of its application range and/or the location where the weed seeds were positioned.

The pots were filled with a dystrophic Red Latosol from the previously sifted arable layer. This soil was collected from an area with no former use of herbicide, and previously characterized in relation to its chemical and physical properties in the ESALQ / USP soil laboratory (table 1).

Unit: $\mathrm{Al}, \mathrm{H}+\mathrm{Al}, \mathrm{K}, \mathrm{Ca}$, $\mathrm{Mg}, \mathrm{SB}$ and CTC (mmol $\mathrm{dm}^{3}$ ); P (resina) (mg $\left.\mathrm{dm}^{-3}\right) ; \mathrm{V}$, clay, silt, sand (\%).

Unidad: $\mathrm{Al}, \mathrm{H}+\mathrm{Al}, \mathrm{K}, \mathrm{Ca}$, $\mathrm{Mg}$, SB y CTC (mmolc $\mathrm{dm}^{-3}$ ); P (resina) (mg $\mathrm{dm}^{-3}$ ); V, arcilla, limo, arena (\%).
Table 1. Result of soil chemical analysis ( 0 to $20 \mathrm{~cm}$ ). Piracicaba - SP.

Tabla 1. Resultado del análisis químico del suelo (0 a $20 \mathrm{~cm}$ ). Piracicaba - SP.

\begin{tabular}{|c|c|c|c|c|c|c|c|c|c|c|c|c|}
\hline $\begin{array}{c}\mathbf{p H} \\
\left(\mathbf{C a C l}_{2}\right)\end{array}$ & $\mathbf{A l}$ & $\mathbf{H + A l}$ & $\begin{array}{c}\mathbf{P} \\
\text { (resina) }\end{array}$ & $\mathbf{K}$ & $\mathbf{C a}$ & $\mathbf{M g}$ & $\mathbf{S B}$ & $\mathbf{C T C}$ & $\mathbf{V}$ & Clay & Silt & Sand \\
\hline 5.3 & $<1.0$ & 25.0 & 10.0 & 2.8 & 26.0 & 13 & 41.8 & 66.8 & 63 & 41.0 & 5.0 & 54.0 \\
\hline
\end{tabular}

Sugarcane straw was removed from a sugarcane field, shortly after harvesting and before herbicide application, avoiding, therefore, field decomposition or herbicide contamination. Afterwards, this straw was air-dried, manually chopped with scissors, and distributed on the pot's surface establishing proportional straw quantities, in tons per hectare, for each treatment $\left(0,1,2,3\right.$, and 5 tha $^{-1}$, respectively).

Following this step, herbicide treatments, amicarbazone $\left(1,400 \mathrm{~g} \mathrm{ha}^{-1}\right)$, metribuzin $(1,920$ $\left.\mathrm{g} \mathrm{ha}^{-1}\right)$, indaziflam $\left(100 \mathrm{~g} \mathrm{ha}^{-1}\right)$, isoxaflutole $\left(105 \mathrm{~g} \mathrm{ha}^{-1}\right)$, amicarbazone + indaziflam $(1,005$ $\left.+75 \mathrm{ha}^{-1}\right)$, indaziflam (75 $\left.\mathrm{g} \mathrm{ha}^{-1}\right)$, metribuzin + indaziflam $\left(960+75 \mathrm{~g} \mathrm{ha}^{-1}\right)$, and isoxaflutole + indaziflam $\left(75+75 \mathrm{~g} \mathrm{ha}^{-1}\right)$ were applied against pre-emergence weeds using a $\mathrm{CO}_{2}$ pressurized spool sprayer carrying a spray bar containing two Teejet 110.02 fan nozzles, with an application volume of $200 \mathrm{~L} \mathrm{ha}^{-1}$. During herbicides application, relative air humidity was $65 \%$, temperature was $26.6^{\circ} \mathrm{C}(10)$, and a wind speed was $2.3 \mathrm{~km} / \mathrm{h}$.

After 24 hours of herbicide application, $30 \mathrm{~mm}$ of water were irrigated with a sprinkler irrigation system ( $1 \mathrm{~L} / \mathrm{min}$ ). Then, the straw was let to dry for 48 hours. Subsequently, the pots were re-watered in a daily basis, with $10 \mathrm{~mm}$, through a sprinkler irrigation system. After $0,30,60$, and 90 days after applying the treatments, all straw was carefully removed, and weeds were sown.

Following the periods of 0,30,60, and 90 DAT (Weeds germination flushes), Sorghum halepense, Rottboellia exaltata, and Mucuna aterrima seeds were individually and carefully sown in the pots, intending a minimum soil turnover. The amount of seed used was sufficient to obtain five plants per pot. For the Mucuna aterrima species, dormancy breakage was achieved through mechanical seed scarification.

At 7, 14, 21, 28, and 35 days after weed emergence (DAE), visual phytotoxicity evaluations were performed based on the Asociación Latino Americana de Las Malezas (1) criteria, 
and according to a percentage scale of grades, where 0 is absence of damage and $100 \%$ is plant death. At $35 \mathrm{DAE}$, the plants were cut close to the soil level, packed in paper bags, and oven dried at $60{ }^{\circ} \mathrm{C}$ for 24 hours, until constant weight.

Each treatment dry mass was interpreted as a reduction percentage in relation to the control treatment. All data were submitted to ANOVA, and means were compared by Tukey test using the AgroEstat computational statistical software (4). When significant, variable effects were analyzed by non-linear regressions, with SIGMAPLOT computational program. Data analysis was individually conducted for each herbicide.

\section{RESUlts}

Weed control is generally considered "very good" when herbicide application achieves 81-90\% control of weeds, and "excellent" with control percentages between 91 and 100\% (1). For highly invasive weeds like Mucuna aterrima, Sorghum halepense, and Rottboellia exaltata, control effectiveness must exceed $90 \%(7,14,17)$.

Indaziflam resulted not effective against Mucuna aterrima. Only during the first emergence period, at 0 DAT, with the application on $0 \mathrm{t} /$ ha, control achieved $80 \%$. For all other treatments, control was considered ineffective, with values under $80 \%$. During the emergence period at $90 \mathrm{DAT}$, and regardless of the amount of straw, control percentages for Mucuna aterrima were under 40\%, (figure 1-A).
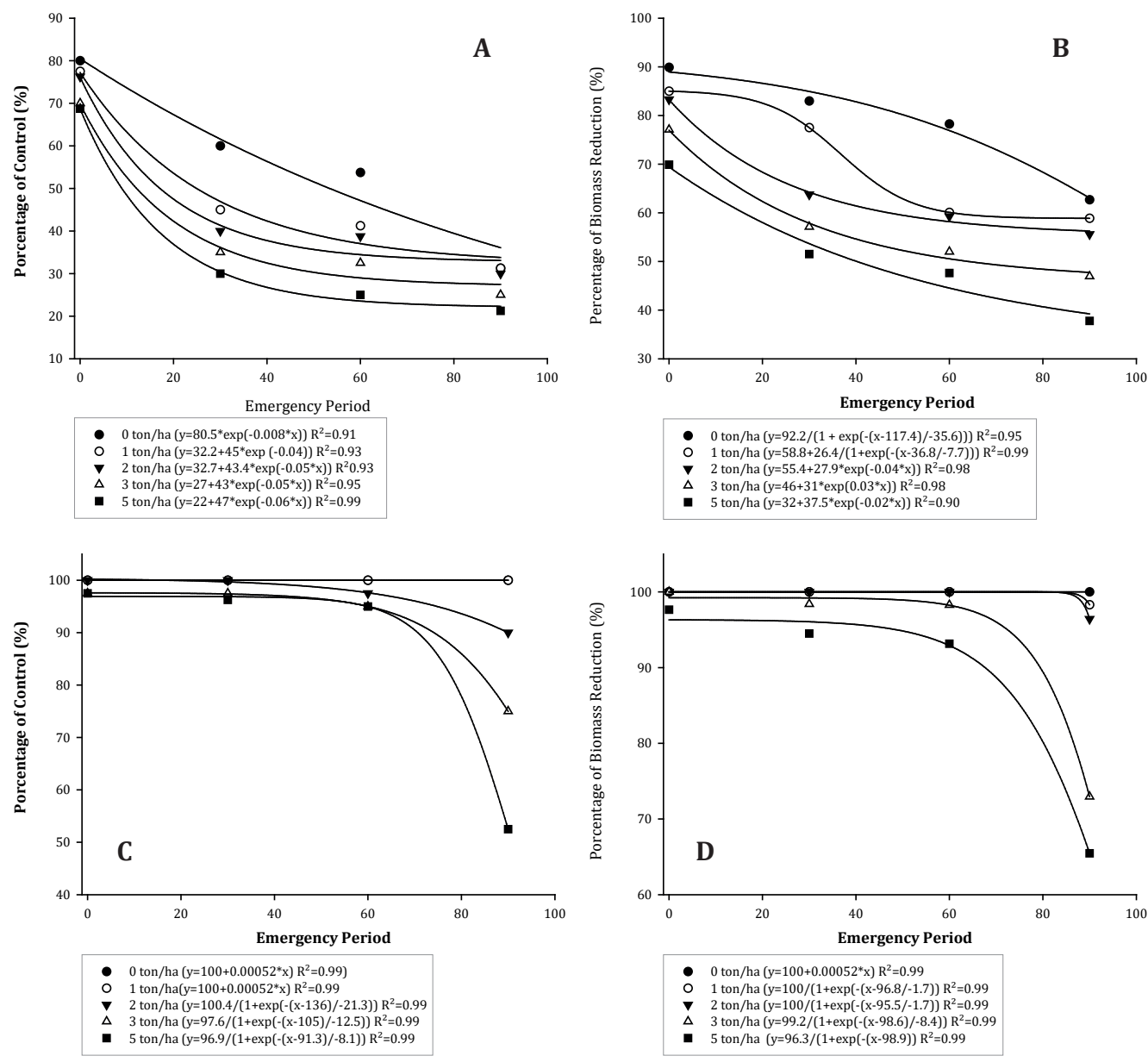

Figure 1. Biomass Control and reduction at 35 DAE with indaziflam: Mucuna aterrima (A-B) and Rottboellia exaltata (C-D).

Figura 1. Control y reducción de la biomasa a 35 DAE a través del herbicida indaziflam: Mucuna aterrima (A-B) y Rottboellia exaltata (C-D). 
Control of Rottboellia exaltata by indaziflam, in the emergence periods at 0,30 , and 60 DAT, was over $80 \%$ for all straw amounts. In the emergence flush at 90 DAT, only for 3 and $5 \mathrm{t} /$ ha of straw, control was ineffective, reaching $75 \%$ and $52.5 \%$, respectively (figure 1-C, page 223). For Sorghum halepense, no statistical difference was observed for biomass reduction and control, however, the latter was considered to be "excellent", with percentages over $90 \%$ in all treatments, (data not shown). Regarding metribuzin, excellent control of Mucuna aterrima was observed in the first emergence period at 0 DAT, where control percentages exceeded 98\%, regardless of straw amount. In the emergence period at 30, 60, and 90 DAT, regardless straw amount, control was inadequate (figure 2-A).
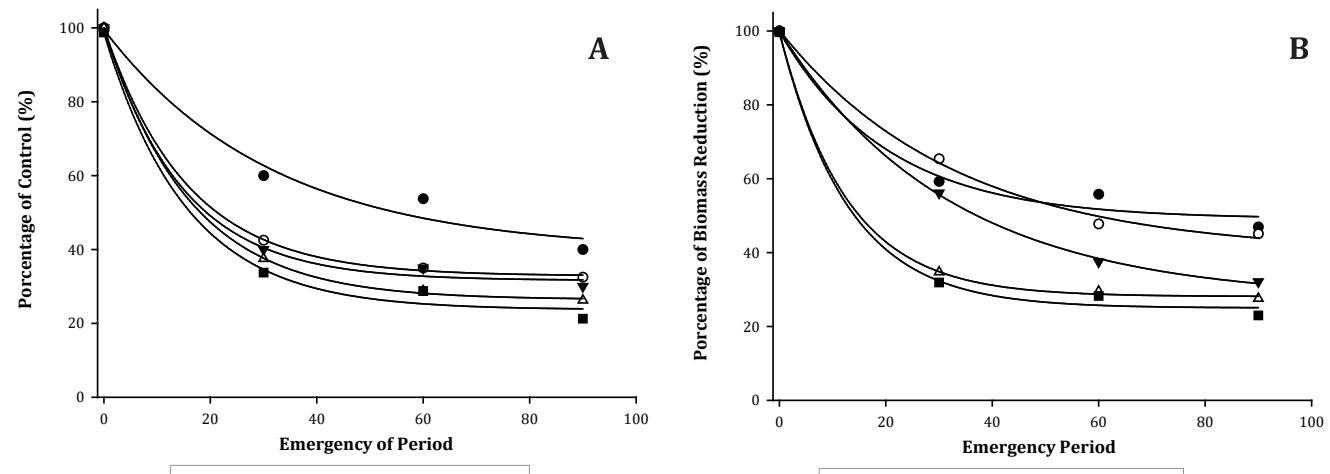

0 ton $/$ ha $\left(y=39.5+60.1^{*} \exp \left(-0.03^{*} x\right) R^{2}=0.93\right.$
1 ton $/$ ha $\left(y=32.8+67.1^{*} \exp \left(-0.06^{*} x\right) R^{2}=0.99\right.$ 2 ton/ha $\left(y=31.6+68.3^{*} \exp \left(-0.06^{*} x\right) R^{2}=0.98\right.$ $\Delta 3$ ton/ha $\left(y 26.4+73.5^{*} \exp \left(-0.06^{*} x\right) \mathrm{R}^{2}=0.99\right.$
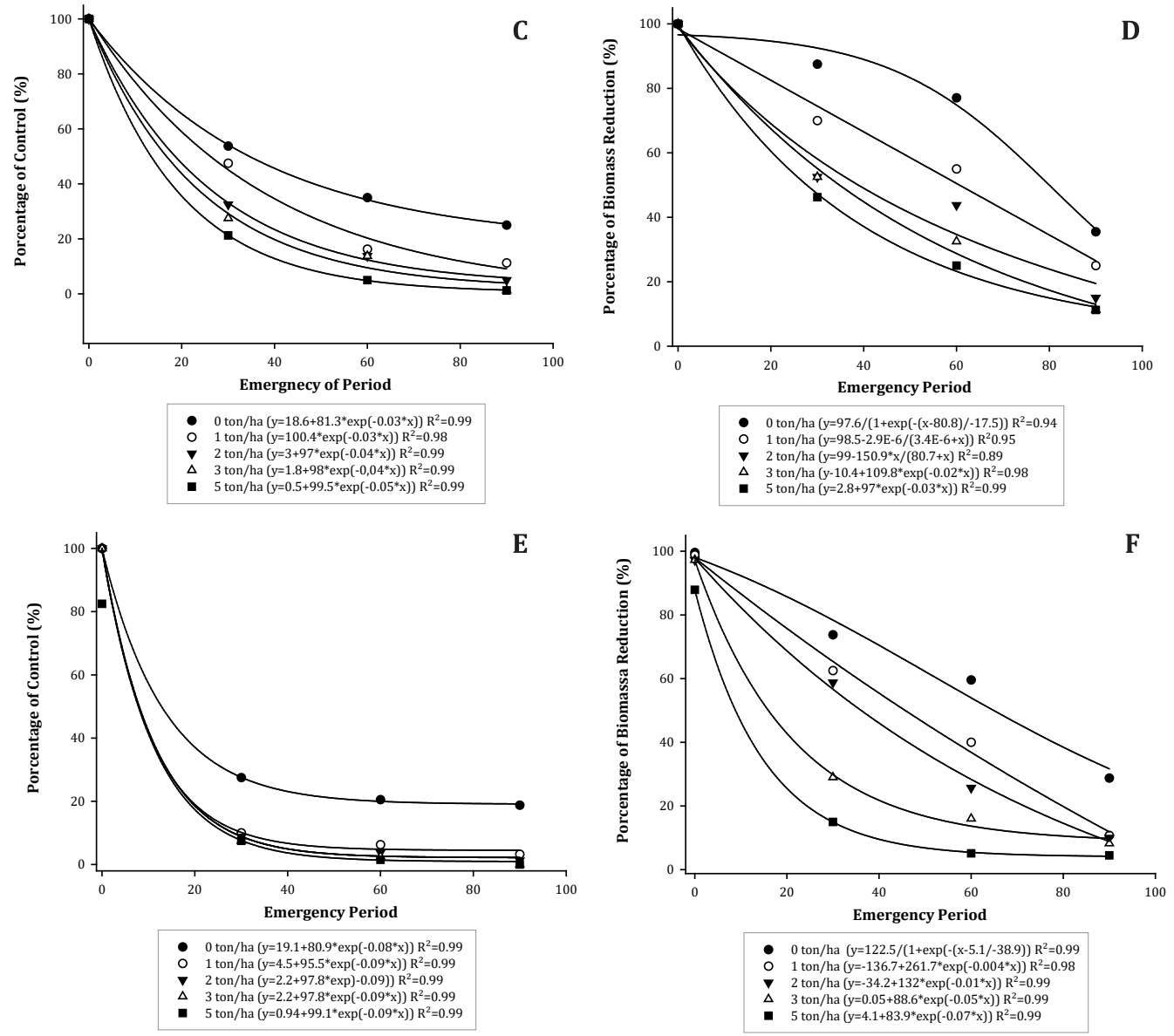

Figure 2. Biomass control and reduction at 35 DAE by metribuzin: Mucuna aterrima (A-B); Sorghum halepense (C-D); and Rottboellia exaltata (E-F).

Figura 2. Control y reducción de la biomasa a 35 DAE a través del herbicida metribuzim: Mucuna aterrima (A-B); Sorghum halepense (C-D) y Rottboellia exaltata (E-F). 
Control of Sorghum halepense and Rottboellia exaltata by metribuzin, in the emergence period at 0 DAT, achieved $100 \%$ independently from straw amounts. However, in the sowing periods of 30,60 , and 90 DAT, this herbicide was not effective against these species, regardless of straw amount (figure 2-C-E, page 224). For isoxaflutole, in the emergence period at 0 DAT, control percentages of Mucuna aterrima were over $80 \%$ when herbicide applications occurred on 0,1 , and $2 \mathrm{t} / \mathrm{ha}$. For 3 and $5 \mathrm{t} / \mathrm{ha}$, control resulted ineffective. In the emergence flushes of Mucuna aterrima at 30,60, and 90 DAT, isoxaflutole was not effective, regardless of straw amount (figure 3-A).
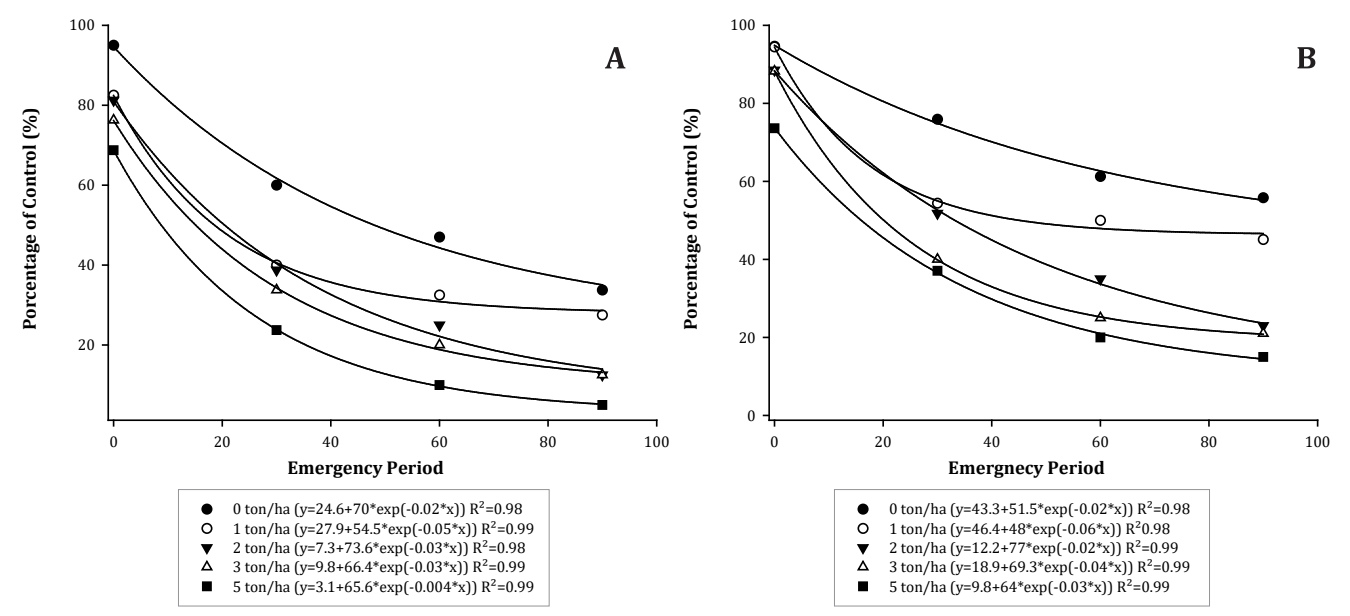

- 0 ton/ha $\left(y=43.3+51.5^{*} \exp \left(-0.02^{*} x\right)\right) R^{2}=0.98$ 1 ton/ha $\left(\mathrm{y}=46.4+48^{*} \exp \left(-0.06^{*} *\right)\right) \mathrm{R}^{2} 0.98$ $\triangle \quad 2$ ton/ha $\left(y=12.2+77^{*} \exp \left(-0.02^{*} \times\right)\right) R^{2}=0.99$ 5 ton/ha $\left(y=3.1+65.6^{*} \exp \left(-0.004^{*} x\right)\right) R^{2}=0.99$
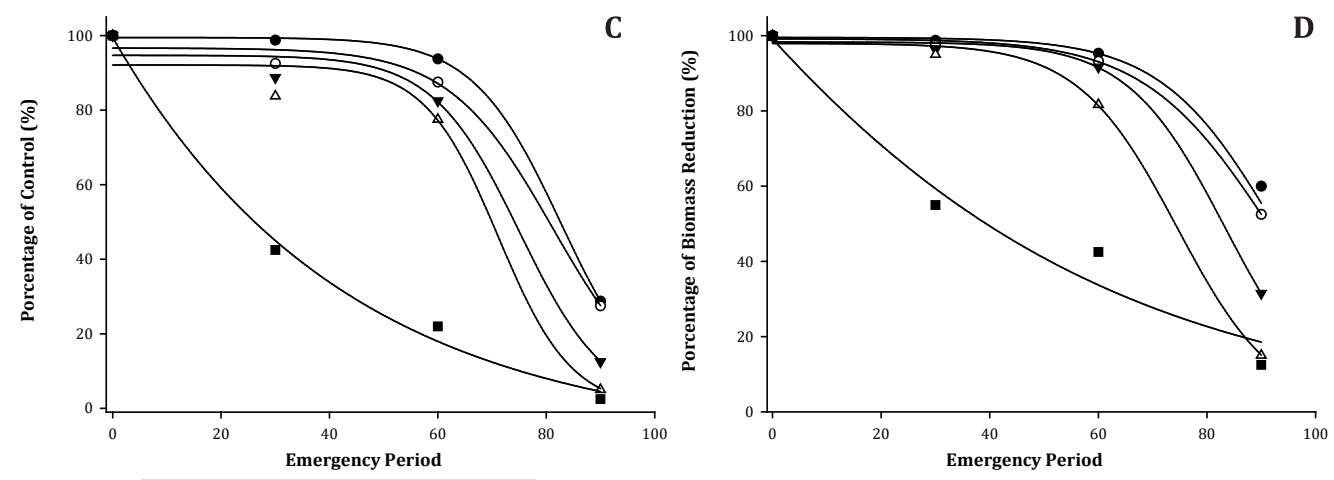

- 0 ton/ha $\left(y=99.5 /(1+\exp (-(x-82.7) /-8.1)) R^{2}=0.99\right.$ - 1 ton/ha $\left(y=96.7 /(1+\exp (-(x-81.2) /-9.6))^{2} R^{2}=0.97\right.$ 2 ton/ha $\left(y=94.7 /(1+\exp (-(x-75) /-8)) \mathrm{R}^{2}=0.96\right.$ 5 ton/ha $\left(y=8.7+1082^{*} \exp \left(-0.02^{*} x\right)\right) R^{2}=0.98$

$\mathbf{E}$

0 ton/ha $\left(y=99.5 /\left(1+\exp (-(x-92.4 /-10.5)) R^{2}=0.99\right.\right.$
$0 \quad 1$ ton/ha $\left(y=99.2 /(1+\exp (-(x-91.4) /-11.5)) \mathrm{R}^{2}=0.99\right.$ 2 ton/ha $\left(y=98.3 /(1+\exp (-(x-83.3)-9)) R^{2}=0.99\right.$

5 ton/ha $\left(y=3956 /(1+\exp (-(x-51.5) / 47)) \mathrm{R}^{2}=089\right.$
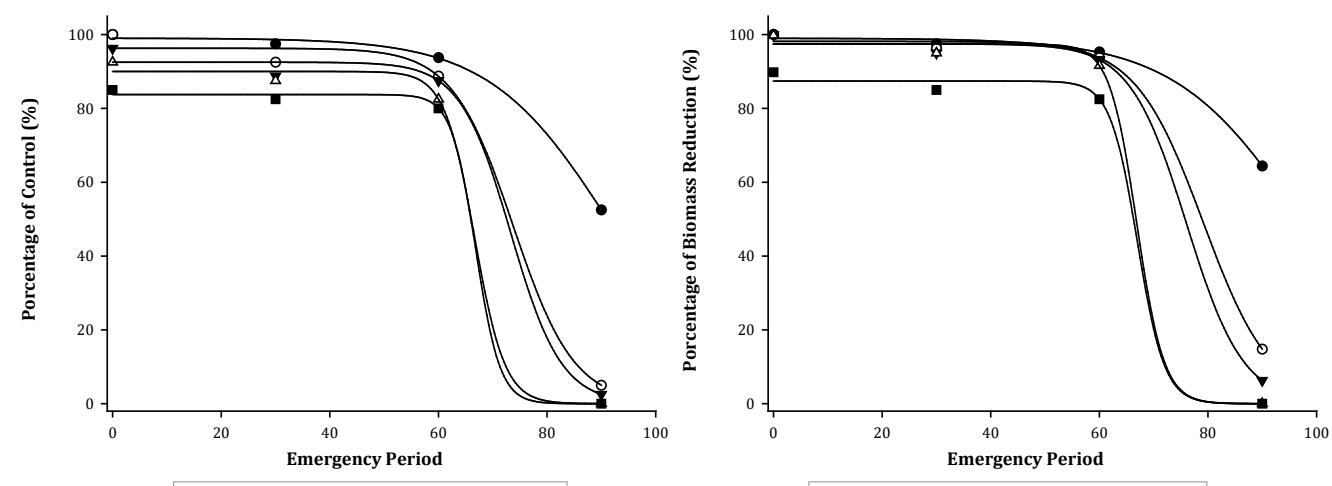

- 0 ton/ha $\left(\mathrm{y}=99 /(1+\exp (-(\mathrm{x}-91.3) /-11)) \mathrm{R}^{2}=0.99\right.$ 1 ton/ha $\left(y=96.3 /(1+\exp (-(x-73.8) / 5.6)) R^{2}=0.98\right.$
2 ton/ha $\left(y=92.5 /(1+\exp (-(x-73.3) /-4.7)) \mathrm{R}^{2}=0.98\right.$ (1) 5 ton/ha $\left(y=83.8 /(1+\exp (-(x-66.9) / 2.2)) \mathrm{R}^{2}=0.99\right.$

- 0 ton/ha $\left(y=99 /(1+\exp (-(x-97.2) /-116.1)) \mathrm{R}^{2}=0.99\right.$ - 1 ton/ha $\left(y=98.2 /(1+\exp (-(x-79.1) /-6.3)) \mathrm{R}^{2}=0.99\right.$ 2 ton/ha $(y=97.5 /(1+\exp (-(x-76.1)) / 5.2)) R^{2}=0.99$ 5 ton $\left(y=87.4 /(1+\exp (-(x-67) /-25)) R^{2}=0.99\right.$

Figure 3. Biomass Control and reduction of at 35 DAE by isoxaflutole: Mucuna aterrima (A-B); Sorghum halepense (C-D); and Rottboellia exaltata (E-F).

Figura 3. Control y reducción de la biomasa a 35 DAE a través del herbicida isoxaflutole: Mucuna aterrima (A-B); Sorghum halepense (C-D) y Rottboellia exaltata (E-F). 
For Sorghum halepense, control through isoxaflutole was considered excellent in the emergence period at 0 DAT, reaching $100 \%$ for all straw amounts. In the emergence period at 30 DAT, control exceeded $80 \%$ for all straw quantities. At 60 DAT, control resulted ineffective for 3 and $5 \mathrm{t} /$ ha of straw and at 90 DAT, regardless of straw amount, control was ineffective (figure 3-C, page 225). Isoxaflutole adequately controlled Rottboellia exaltata, (above 80\%) at 0, 30, and 60 DAT for all straw amounts, while at 90 DAT, control was ineffective, regardless of straw quantities (figure 3-E, page 225).

Amicarbazone, in the emergence period at 0 DAT, provided excellent control of Mucuna aterrima, with percentages over $93 \%$ for all amounts of straw. At 30 DAT, for 0, 1, and 3 t/ ha, control was excellent, over 95\%. For 5 t/ha, control was adequate. For the 60 DAT emergence period, and 0,1 , and $2 \mathrm{t} / \mathrm{ha}$, control exceeded $90 \%$ but resulted inefficient for the applications on 3 and $5 \mathrm{t} /$ ha of straw. At 90 DAT, control was effective only in the absence of straw, exceeding 90\% (figure 4-A, page 227). Regarding Sorghum halepense and Rottboellia exaltata, when amicarbazone was applied at 0 DAT, and for all amounts of straw, control exceeded 85\%. At 30,60, and 90 DAT, control of these species was considered ineffective, regardless of straw quantities (figure 4-C-E, page 227).

At 0 DAT emergence period, the association between indaziflam and isoxaflutole resulted effective against Mucuna aterrima for all amounts of straw, exceeding 80\%. At the 30,60, and 90 DAT emergence periods, control was considered ineffective, regardless of straw amount (figure 5-A, page 228). Control of Sorghum halepense by the association of indaziflam with isoxaflutole, at 0 DAT, was $100 \%$ for all amounts of straw. In the 30 DAT emergence period , regardless of straws amounts, control exceeded 90\%. At 60 and 90 DAT, for 0, 1, 2, and 3 t/ha, control was over 90\%; while in 5 t/ha, control was over $80 \%$ (figure 5 -C, page 228). Rottboellia exaltata treated with indaziflam + isoxaflutole, at 0 DAT, exceeded $95 \%$ for all amounts of straw. At 30, 60, and 90 DAT, control of Rottboellia exaltata achieved over 85\% for $0,1,2$, and $3 \mathrm{t} /$ ha. However, for $5 \mathrm{t} / \mathrm{ha}$, control was below $75 \%$ at all emergence periods (figure 5-E, page 228).

Control of Mucuna aterrima, by application of indaziflam associated with amicarbazone, can be observed in figure 6-A (page 229). In the 0 DAT emergence period, control was ineffective only for $5 \mathrm{t}$ /ha of straw. At 30 DAT, control was acceptable only for straw quantities of 0 and $1 \mathrm{t} / \mathrm{ha}$, achieving control percentages of $87.5 \%$ and $83.75 \%$, respectively. For the 60 DAT emergence period and 0 t/ha of straw, control was $81.25 \%$. For the other straw quantities, weed control was below $80 \%$. Regarding the emergence period at $90 \mathrm{DAT}$, for any amount of straw, control percentages were lower than $52.5 \%$.

The application of amicarbazone + indaziflam resulted in excellent control of Sorghum halepense during the emergence period at 0 DAT, with control percentages higher than 98\% for all straw amounts. At 30,60, and 90 DAT, control was considered ineffective only for the amount of $5 \mathrm{t} / \mathrm{ha}$, but exceeded $90 \%$ for 0,1 , 2, and $3 \mathrm{t} /$ ha (figure 6-C, page 229). Control of Rottboellia exaltata through the association between indaziflam and amicarbazone, achieved $100 \%$ at 0 and 30 DAT, for all straw amounts, while it also achieved $100 \%$ at 60 DAT with 0,1 , and $2 \mathrm{t} /$ ha straw. However, with amounts of straw of 3 and $5 \mathrm{t} / \mathrm{ha}$, control was 95 and $80 \%$, respectively. In the emergence period at 90 DAT, control was considered effective only for straw quantities of 0 and $1 \mathrm{t} / \mathrm{ha}$, with $96.25 \%$ and $92.50 \%$, respectively (figure 6-E, page 229).

For Mucuna aterrima, results on the association of indaziflam with metribuzin can be observed in Figure 7 (page 230). In the emergency periods at 0 DAT, control was above 80\%, regardless of straw amounts. At $30 \mathrm{DAT}$, only for $5 \mathrm{t} / \mathrm{ha}$, control was considered ineffective, with percentages below $80 \%$, while at 60 DAT, only in the absence of straw, control was effective. At 90 DAT, and for all amounts of straw, control was under 80\% (figure 7-A, page 230).

Control of Sorghum halepense using indaziflam associated with metribuzin, at 0 DAT, was above $90 \%$, regardless of straw amounts. In the 30 and 60 DAT emergence periods, control was only considered inadequate for $5 \mathrm{t} /$ ha of straw. At 90 DAT, ineffective control was found only in applications of 3 and 5 t/ha, with 67.5 and $45 \%$ control, respectively (figure 7-C, page 230). For Rottboellia exaltata, application of indaziflam associated with metribuzin, for 0,30 , and 60 DAT emergence periods, achieved excellent control exceeding $87.5 \%$, for all amounts of straw. However, at 90 DAT, no effective control of Rottboellia exaltata was observed for 3 and 5 t/ha (figure 7-E, page 230). 

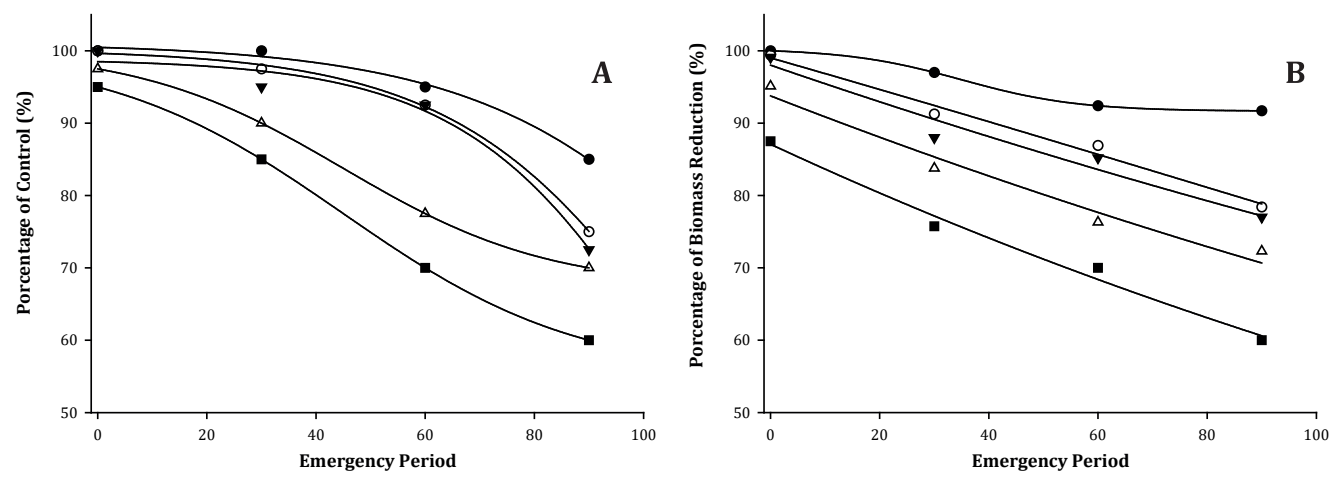

- 0 ton/ha $\left(y=101.1 /(1+\exp (-(x-133) /-25.9)) \mathrm{R}^{2}=0.98\right.$

1 ton/ha $\left(y=100.2 /(1+\exp (-(x-114.1) /-22.1)) \mathrm{R}^{2}=0.9\right.$

2 ton/ha $\left(y=98.9 /(1+\exp (-(x-110) /-19.7)) R^{2}=0.94\right.$
3 ton/ha $\left(y=67.2+33.1 /(1+\exp (-(-x-45) /-18.9)) R^{2}=0.99\right.$

- 0 ton/ha $\left(y=91.7+86 /(1+\exp (-(x-35.1) /-10.6)) \mathrm{R}^{2}=0.99\right.$

1 ton/ha $(y=160.1 /(1+\exp (-(x-8-4.4) / 1) / 175.2)) \mathrm{R}^{2}=0.95$

$\Delta 3$ ton/ha $\left(y=93.8^{*} \exp \left(-0.003^{*} \times\right)\right) R^{2}=0.95$

5 ton/ha $\left(y=55+45 /(1+\exp (-(x-45) / 21.7)) \mathrm{R}^{2}=0.99\right.$
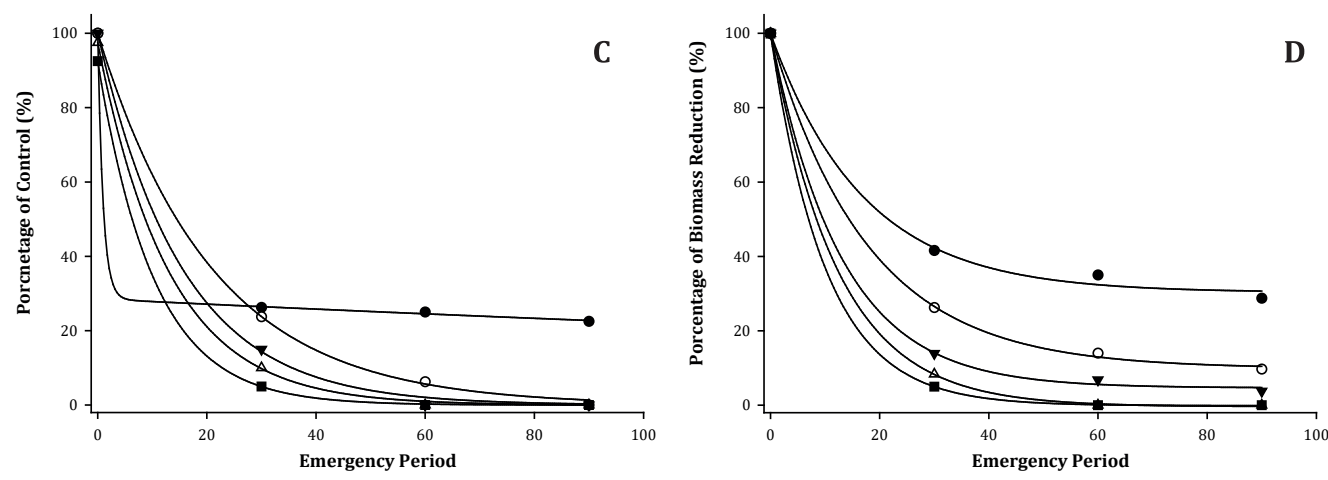

0 ton/ha $\left(y=71.5^{*} \exp \left(-1.11^{*} x\right)+28.5 * \exp \left(-0.003^{*} x\right)\right) R^{2}=0.99$

1 ton/ha $\left(y=100^{*} \exp (-0.058 x)\right) R^{2}=0.99$

3 ton/ha $\left(y=97.5^{*} \exp \left(-0.07^{*} x\right)\right) R^{2} 0=0.99$

5 ton/ha $\left(y=92.5^{*} \exp \left(-0.1^{*} x\right)\right) R^{2}=0.99$

- 0 ton/ha $\left(y=30.3+69.6^{*} \exp \left(-0.06^{*} x\right)\right) R^{2}=0.99$

2 ton/ha $(y=4.7+95.3 * \exp (-0.08 * x)) R^{2}=0.99$

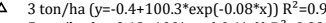

- 5 ton/ha $\left(\mathrm{y}=0.13+100^{*} \exp \left(-0.1^{*} \mathrm{x}\right)\right) \mathrm{R}^{2}=0.99$
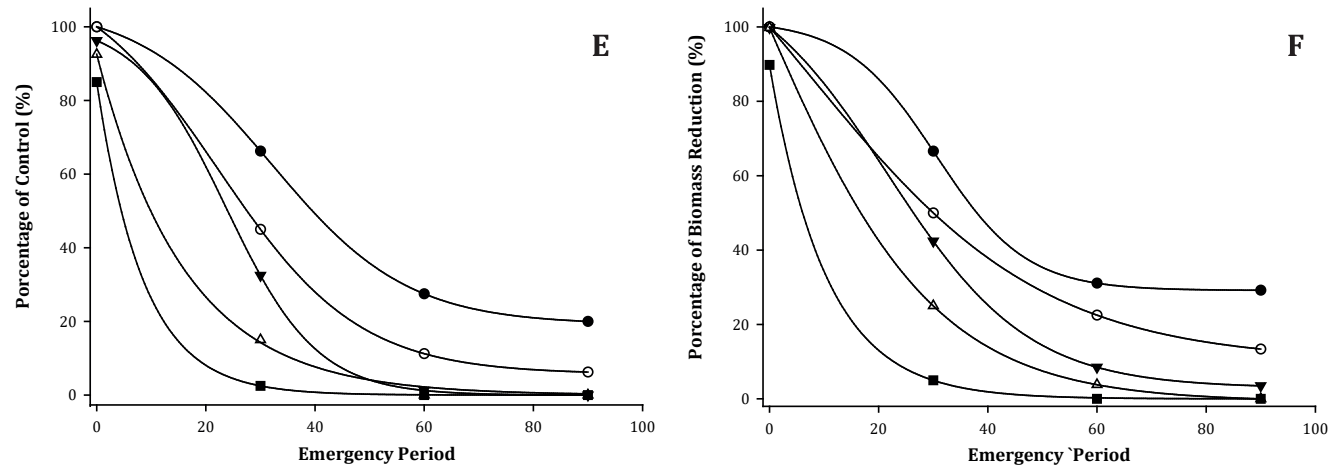

- 0 ton/ha $\left(y=19.2+87 /(1+\exp (-(x-32) /-12.4)) \mathrm{R}^{2}=0.99\right.$

1 ton/ha $\left(y=5.7+110.8 /(1+\exp (-(x-22.3) /-12.8)) R^{2}=0.99\right.$

2 ton/ha $\left(y=-0.04+101.9(1+\exp (-(x-23.7)-8.3)) \mathrm{R}^{2}=0.99\right.$

5 ton/ha $(y=85 * \exp (-0.1 * x)) \mathrm{R}^{2}=0.99$

- 0 ton/ha $\left(y=29.1+72.6 /(1+\exp (-(x-30.5) /-8.2)) \mathrm{R}^{2}=0.99\right.$

1 ton/ha $\left(y=10.1+15.5 /(1+\exp (-(x-7) /-21.7)) R^{2}=0.99\right.$

2 ton/la $\left(y=2.9+15 /(1+\exp (-(x-21.7) / 12.9)) \mathrm{R}^{2}=0.99\right.$

5 ton $/$ ha $\left(y=89.8^{*} \exp \left(-0.1^{*} x\right)\right) R^{2}=0.99$

Figure 4. Biomass control and reduction at 35 DAE by amicarbazone: Mucuna aterrima (A-B); Sorghum halepense (C-D); and Rottboellia exaltata (E-F).

Figura 4. Control y reducción de la biomasa a 35 DAE a través del herbicida amicarbazona: Mucuna aterrima (A-B); Sorghum halepense (C-D) y Rottboellia exaltata (E-F). 

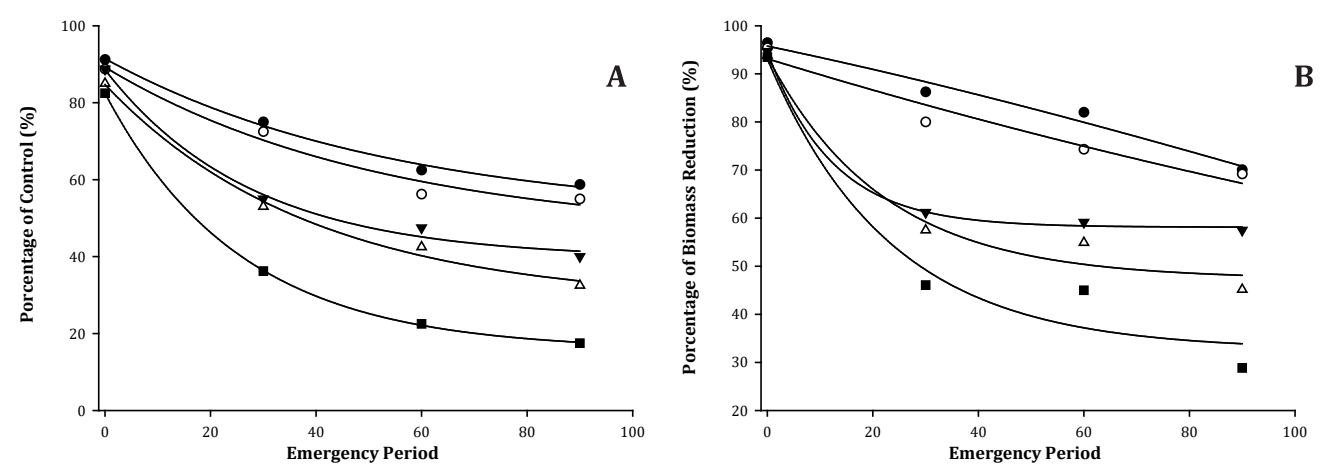

0 ton/ha $\left(y=50.1+41,4^{*} \exp \left(-0.02^{*} x\right)\right) R^{2}=0.98$
1 ton $/$ ha $\left(y=45.6+43.7^{*} \exp \left(-0.02^{*} \mathrm{x}\right)\right) \mathrm{R}^{2}=0.98$

2 ton/ha $\left(y=39.5+49.1^{*} \exp \left(-0.04^{*} x\right)\right) R^{2}=0.98$

5 ton/h $\left(y=158+667^{*}\left(0 x p(-0.04 * x) R^{2}=0.99\right.\right.$
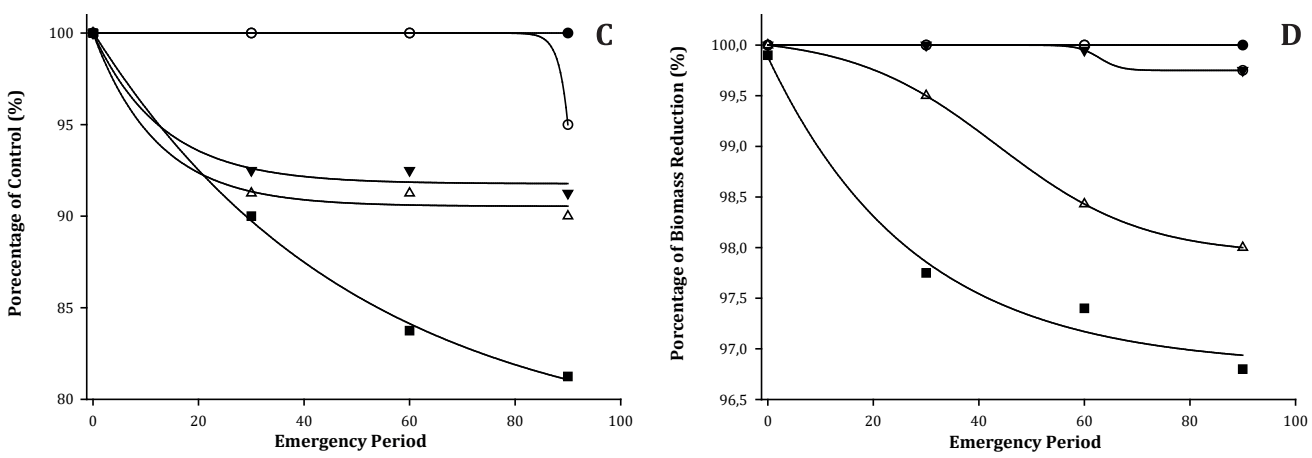

0 ton $\left./ \mathrm{ha}\left(\mathrm{y}=100+5.2 \mathrm{R}-17^{*} \mathrm{x}\right)\right) \mathrm{R}^{2}=0.9$

1 ton/ha $(y=100 /(1+\exp (-(x-94.8)) / 1.6)) R^{2}=0$.

2 ton/ha $\left(y=91.8+82^{*} \exp \left(-0.08^{*} x\right)\right) R^{2}=0.95$

3 ton/ha $\left(y=91+9.5^{*} \exp \left(-0.08^{*} \mathrm{x}\right)\right) \mathrm{R}^{2}=0.96$
5 ton $/ \mathrm{ha}\left(\mathrm{y}=77.4+22.7^{*} \exp \left(-0.02^{*} \mathrm{x}\right)\right) \mathrm{R}^{2}=0.9$

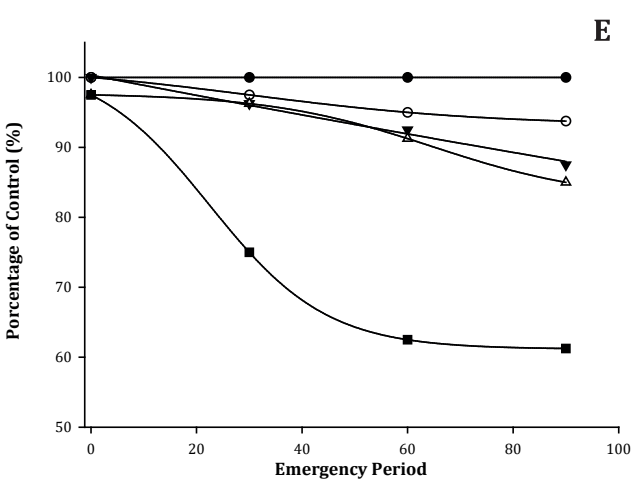

- 0 ton/ha $\left(y=125.5 /(1+\exp (-(x-115.4) /-98.7)) \mathrm{R}^{2}=0.92\right.$

1 ton $/$ ha $\left(y=93.2^{*} \exp \left(-0.004^{*} x\right)\right) R^{2}=0.91$

2 ton/ha $\left(y=58.1+36.5^{*} \exp \left(-0.008^{*} x\right)\right) R^{2}=0.99$

5 ton/ha $\left(y=36.6+60 * * x p\left(-0.04^{*} x\right)\right) R^{2}=0.87$

1 ton/ha $\left(y=93.2+8.7 /(1+\exp (-(x-30) /-22.8)) R^{2}=0.99\right.$ 2 ton/ha $\left(y=100.3^{*} \exp (-0.002 * x)\right) R^{2}=0.99$

3 ton/ha $\left(y=82.5+15.2 /(1+\exp (-(x-64.7)-15.6)) R^{2}=0.99\right.$ 5 ton/ha $\left(y=61.2+41.1 /(1+\exp (-(x-22.5) /-11.1)) \mathrm{R}^{2}=0.99\right.$

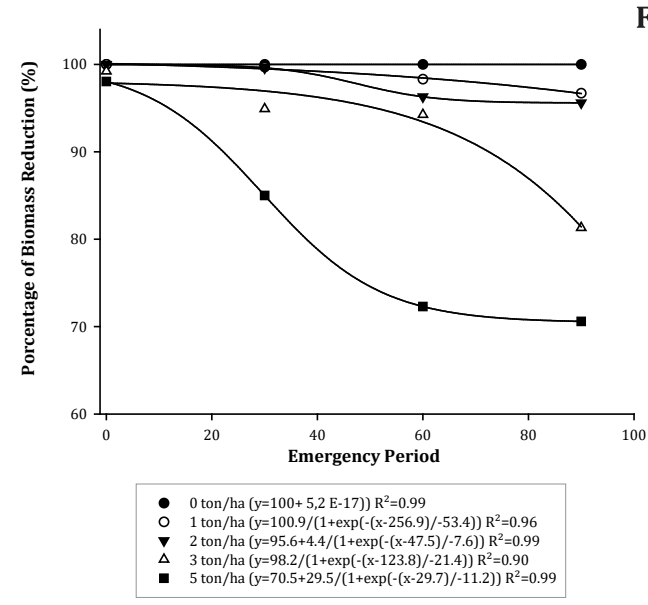

Figure 5. Biomass control and reduction at 35 DAE through indaziflam + isoxaflutole: Mucuna aterrima (A-B); Sorghum halepense (C-D); and Rottboellia exaltata (E-F).

Figura 5. Control y reducción de la biomasa a 35 DAE a través del herbicida indaziflam + isoxaflutole: Mucuna aterrima (A-B); Sorghum halepense (C-D) y Rottboellia exaltata (E-F). 

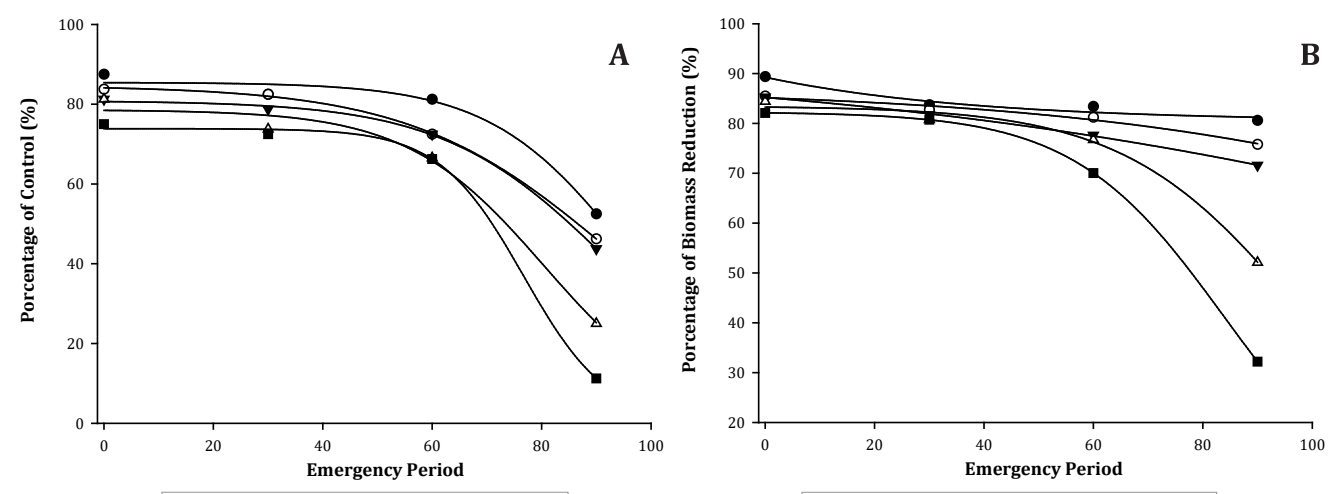

- 0 ton/ha $\left(y=85.5 /(1+\exp (-(x-95.9) /-12.6)) \mathrm{R}^{2}=0.96\right.$

- 1 ton/la $\left(y=84.68\left(1+\exp ((-x-95.9) / 12.6) R^{2}=0.96\right.\right.$

3 ton/ha $\left(y=78.6 /(1+\exp (-(x-80.6) /-12.6)) R^{2}=0.96\right.$
5 ton/ha $\left(y=73.9 /(1+\exp (-(-x-76.7) /-7.8)) R^{2}=0.99\right.$

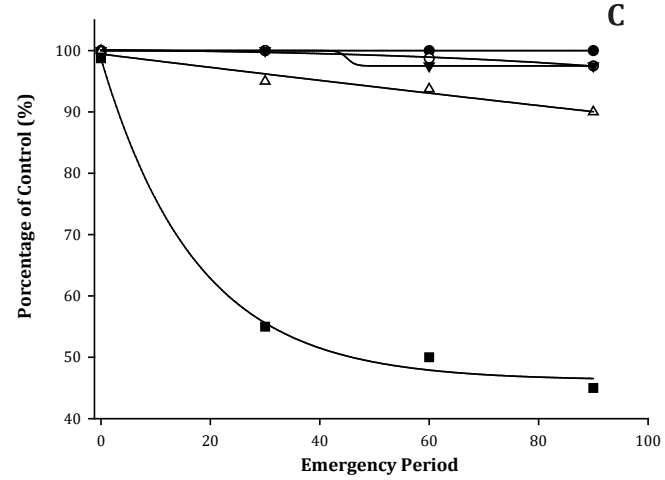

C

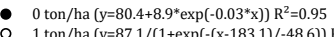

2 ton/ha $\left(y=92.7 /(1+\exp (-(x-181.3) /-74.7)) R^{2}=0.99\right.$

3 ton/ha $\left(y=83.5 /(1+\exp (-(x-98.3) /-16.2)) R^{2}=0.98\right.$

5 ton/ha $\left(y=82.3 /(1+\exp (-(x-83.9) / 13.7)) R^{2}=0.99\right.$

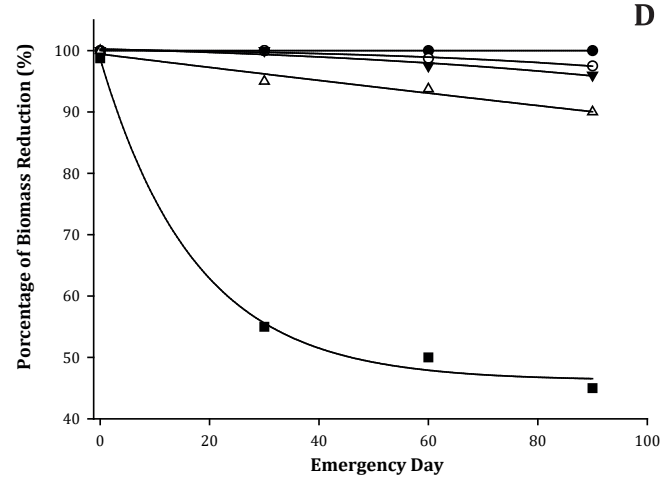

- 0 ton/ha $\left(y=100 /(1+\exp (-(x+6.8) / 0.3)) \mathrm{R}^{2}=0.99\right.$

1 ton/ha $\left(y=100.6 /(1+\exp (-(x-248.7) / 46.2)) \mathrm{R}^{2}=0.96\right.$

2 ton/ha $\left(y=97.5+2.5 /(1+\exp (-(x-45) /-0.8)) R^{2}=0.99\right.$

5 ton $/ \mathrm{ha}\left(\mathrm{y}=46.2+0.06^{*} \exp \left(-0.06^{*} \mathrm{x}\right)\right) \mathrm{R}^{2}=0.98$

- 0 ton/ha $\left.\left(y=100+5.2 \mathrm{E}-17^{*} \mathrm{x}\right)\right) \mathrm{R}^{2}=0.99$

1 ton/ha $\left(y=100.6 /(1+\exp (-(x-248.7) /-46.2)) R^{2}=0.96\right.$

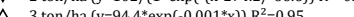

5 ton/ha $\left(y=46.2+52.5^{*} \exp \left(-0.006^{*} x\right)\right) R^{2}=0.99$
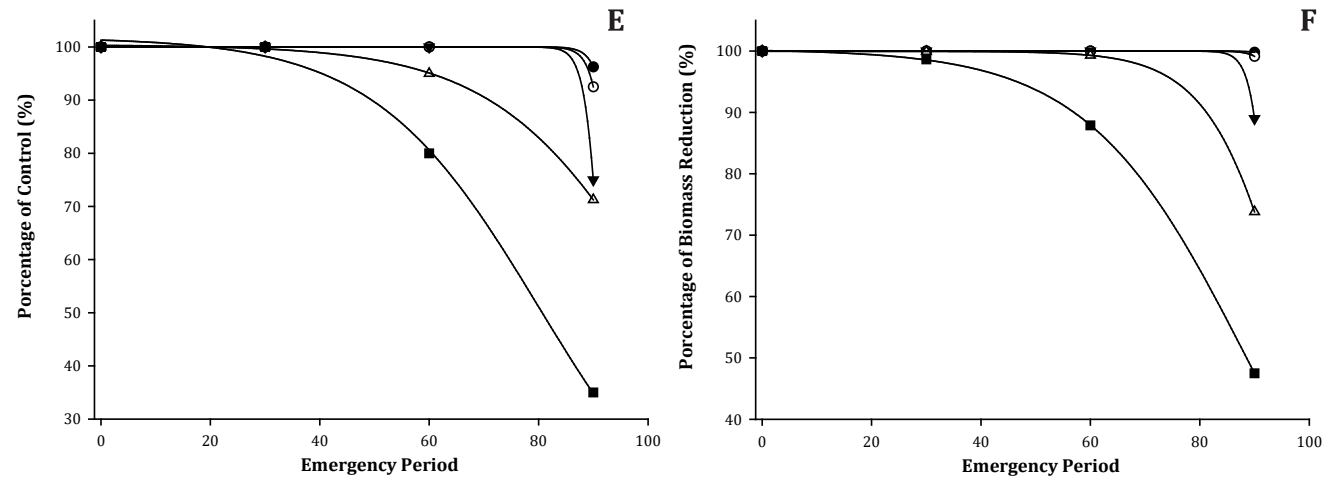

0 ton/ha $\left(y=100 /(1+\exp (-(x-95.2) /-1.6)) \mathrm{R}^{2}=0.99\right.$

1 ton/ha $\left(y=100 /(1+\exp (-(x-94) /-1.6)) \mathrm{R}^{2}=0.99\right.$

2 ton/ha $\left(y=100 /(1+\exp (-(x-91.6) /-1.5)) R^{2}=0.99\right.$

5 ton/ha $\left(y=101.8 /(1+\exp (-(x-80.1) /-15)) R^{2}=0.99\right.$

0 ton/ha $\left(y=100 /(1+\exp (-(x-101.7) /-1.9)) R^{2}=0.99\right.$

1 ton/ha $\left(y=100 /(1+\exp (-(x-98.2) /-1.7)) R^{2}=0.99\right.$

2 ton/ha $\left(y=100 /(1+\exp (-(x-93.2) /-1.6)) R^{2}=0.99\right.$
3 ton/ha $\left(y=99.9 /(1+\exp (-(-x-97.8) /-7.5)) R^{2}=0.99\right.$

$\Delta$ ton/ha $\left(y=99.9 /(1+\exp (-(x-97.8) /-7.5)) R^{2}=0.99\right.$
- 5 ton/ha $\left(y=100.3 /(1+\exp (-(x-88.5) /-14.5)) R^{2}=0.99\right.$

Figure 6. Biomass control and reduction at 35 DAE through indaziflam + amicarbazone: Mucuna aterrima (A-B); Sorghum halepense (C-D); y Rottboellia exaltata (E-F).

Figura 6. Control y reducción de la biomasa a 35 DAE a través del herbicida indaziflam + amicarbazone: Mucuna aterrima (A-B); Sorghum halepense (C-D) and Rottboellia exaltata (E-F). 

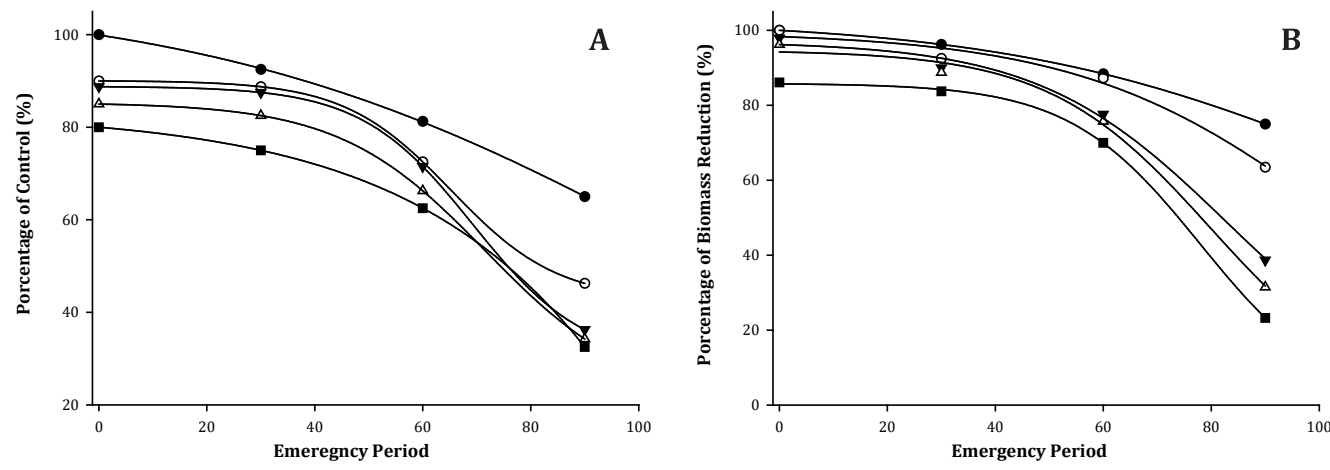

- 0 ton/ha $\left(y=108.6 /(1+\exp (-(x-107.7) /-44.1)) R^{2}=0.99\right.$

1 ton/ha $\left(y=42.6+47.4 /(1+\exp (-(x-65.3) /-9.9)) R^{2}=0.99\right.$
2 ton/ha $\left(y=29.1+59.7 /(1+\exp (-(x-69.3) / 10.4)) R^{2}=0.99\right.$

3 ton/ha $\left(y=71.6+64.2 /(1+\exp (-(x-71.6) /-13.5)) R^{2}=0.99\right.$

- 5 ton/ha $\left(y=570.7+654 /(1+\exp (-(x-168.7) /-31.8)) \mathrm{R}^{2}=0.99\right.$

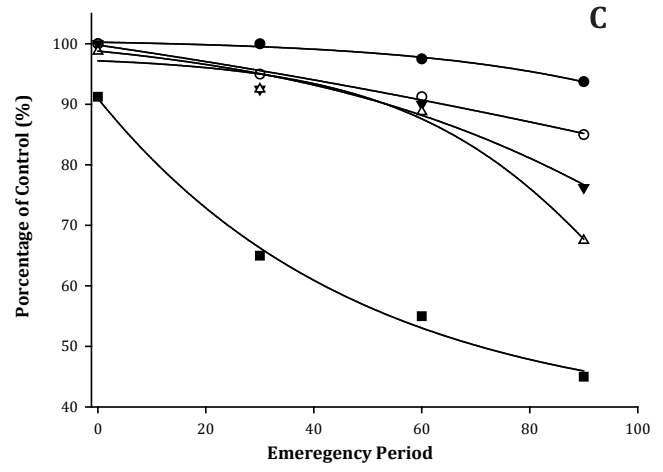

- 0 ton/ha $\left(\mathrm{y}=29.6+73.1 /\left(1+\exp (-(\mathrm{x}-106.1) / 32.6) \mathrm{R}^{2}=0.99\right.\right.$

7 2 ton/ha $\left(\mathrm{y}=97.1 /(1+\exp (-(\mathrm{x}-83.1) /-17.5)) \mathrm{R}^{2}=0.98\right.$

3 ton $/$ ha $\left(y=94.7 /(1+\exp (-(x-79.8) / 14.9)) \mathrm{R}^{2}=0.99\right.$

- 5 ton/ha $\left(y=85.9 /(1+\exp (-(x-78) /-12.2)) R^{2}=0.99\right.$

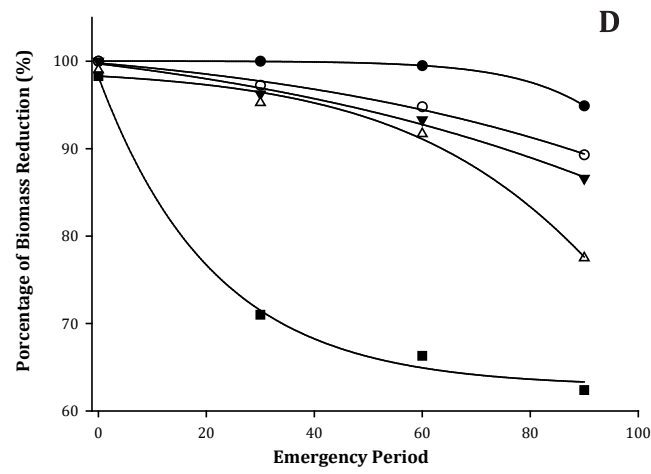

0 ton/ha $\left(y=100.8 /\left(1+\exp (-(-(x-176.3) / 33.4)) \mathrm{R}^{2}=0.98\right.\right.$

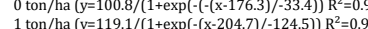

2 ton/ha $\left(y=102.6 /(1+\exp (-(x-135) /-41.4)) R^{2}=0.96\right.$

3 ton/ha $(y=98 /(1+\exp (-(x-108.2)) /-22.7)) R^{2}=0.98$
5 ton/ha $\left(y=37.7+52.2^{*} \exp \left(-0.02^{*} \times\right)\right) R^{2}=0.98$

- 0 ton/ha $\left(y=100 /(1+\exp (-(x-127.5) /-12.9)) \mathrm{R}^{2}=0.99\right.$

2 ton/ha $\left(y=104.6 /(1+\exp (-(x-189.3) /-62.9)) R^{2}=0.97\right.$

3 ton/ha $\left(y=99.2 /(1+\exp (-(x-123.7) /-26.3)) R^{2}=0.97\right.$

5 ton $/ \mathrm{ha}\left(\mathrm{y}=62.8+35.5^{*} \exp \left(-0.05^{*} \mathrm{x}\right)\right) \mathrm{R}^{2}=0.98$
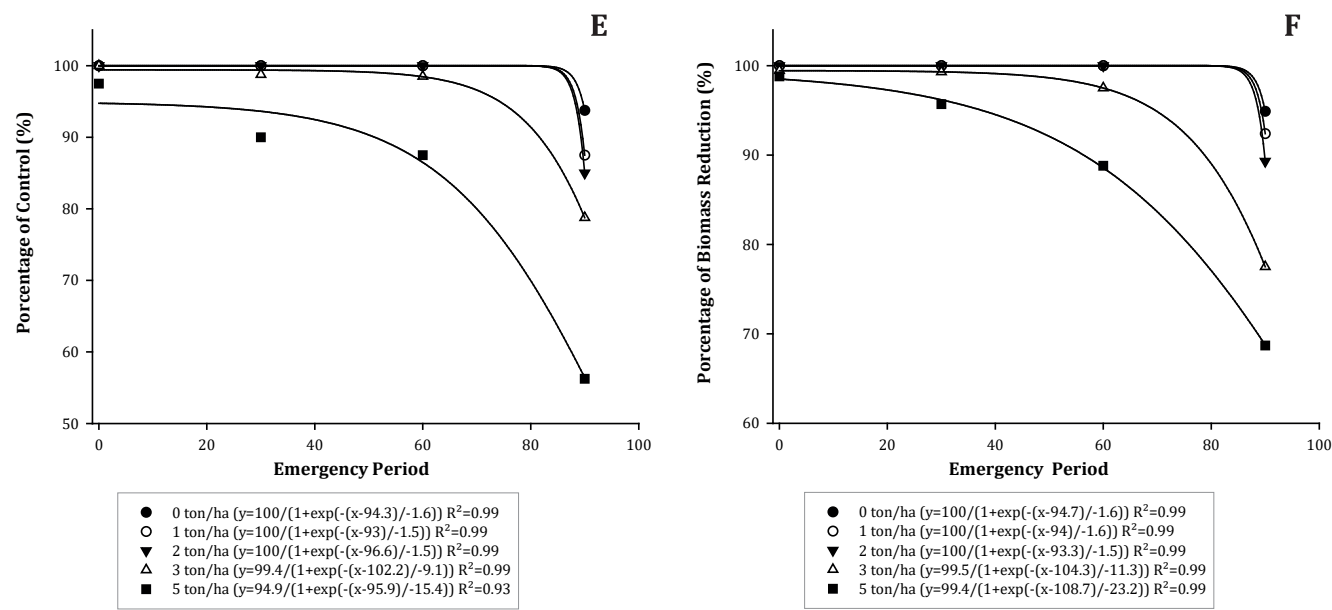

Figure 7. Control and reduction of biomass at 35 DAE through the indaziflam + metribuzin herbicide: Mucuna aterrima (A-B); Sorghum halepense (C-D); and Rottboellia exaltata (D-E).

Figura 7. Control y reducción de la biomasa a 35 DAE a través del herbicida indaziflam + metribuzin: Mucuna aterrima (A-B); Sorghum halepense (C-D) y Rottboellia exaltata (E-F). 


\section{Discussion}

The results obtained for the isolated application of indaziflam indicated that this herbicide achieves better control over monocotyledonous species than over eudicot species. This can be explained by the long soil residual effect of indaziflam (more than 150 days). However, this residual effect might be lower in tropical regions, such as Brazil, with higher temperatures and abundant rainfall (2). Soil moisture is essential for the bioavailability of indaziflam in the soil solution, favouring its effectiveness. This factor turns crucial for sugarcane, where herbicide applications occur during wet, semi-humid, and dry conditions $(6,18)$. The results obtained in this experiment indicated that higher control efficiency with indaziflam is achieved when applied during rainy seasons, given its high Kow and Kd $(18,19)$. Sebastian et al. (2016), verified soil moisture influence over Kochia scoparia L control, confirming this behaviour. Water potential of $-400 \mathrm{KPa}$ resulted in a 100\% dry mass reduction, while $-100 \mathrm{KPa}$ concluded in a dry mass decrease of almost 30\%. That is, the higher the amount of soil water, the higher the effectiveness of indaziflam against Kochia scoparia.

The ineffective control of $R$. exaltata at 90 DAT with indaziflam and 3 and 5 t/ha straw, may have been conditioned by interception and/or adsorption. With Kow $=2.88$, the amount of herbicide transported to the soil and its consequent availability in soil solution, is reduced (6).

In short, we consider that metribuzin did not present lasting soil residue effect. This herbicide presents high water solubility (1100 mg L-1), medium Koc (60 mL g ${ }^{-1}$ ), and a half-life of 30 to 60 days $(12,19)$. Given these physicochemical characteristics, for sugarcane, metribuzin is often applied during the dry season (3). Ben et al. (2015), performing leaching and persistence experiments of metribuzin, using bioindicators (Cucumis sativus), verified that increasing soil water blade resulted in a gradual increase in the control of $C$. sativus. With a water depth of $100 \mathrm{~mm}$, satisfactory control (>96\%) was observed down to the layer of 20-25 cm depth, indicating high leaching potential of metribuzin, mainly for applications during rainy seasons.

For isoxaflutole (IFT), the results suggest a sort of degradation route or alternate transport, making it unavailable for the weed root system. IFT is considered a pro-herbicide that is later converted to diketonitrile (DKN), the active weed controlling molecule (19), depending on soil water availability. In the present experiment, IFT was applied during the wet season and maintained throughout the experiment with constant rainfall $(10 \mathrm{~mm}$ daily). This application may have resulted in the fast conversion of IFT to DKN, making DKN available in the soil solution and susceptible to leaching and degradation phenomena (19). Another aspect that may explain the inadequate control achieved by IFT during the sowing period at 90 DAT, is the short, 56 days half-life of DKN, (19).

The application of amicarbazone, with constant rainfall after application, may have resulted in an intense leaching and a subsequent reduction of its weed control efficiency, due to its high solubility (4,600 mg / L in the range of pH 4-9) (19). Possamai et al. (2013) found high amicarbazone leach in the $60 \mathrm{~mm}$ blade of water in sandy soils, resulting in a lower residual effect for this herbicide. In clay soil, simulations of water depths of 20 and 80 $\mathrm{mm}$ after amicarbazone applications reduced plant biomass at 5-10 $\mathrm{cm}$ depths.

The indaziflam + isoxaflutole association can be considered a good option for monocotyledon weed control, since they have a wide control spectrum for monocots. This association was based on two products with very different physicochemical characteristics: indaziflam has low solubility and high Kow, while DKN (after conversion of IFT in water) has high solubility and low Kow. The combination of contrasting characteristics may have favoured an adequate amount of herbicide in the weed sowing range, achieving proper control of monocotyledon weeds. On the other hand, this association did not increase weed control spectrum, keeping effectiveness only upon monocots.

The association between indaziflam and amicarbazone was not a viable alternative to weed control in this experiment. Isolated applications achieved better results against Mucuna aterrima and Rottboellia exaltata, while Sorghum halepense could not be combated in applications on higher amounts of straw.

The association between indaziflam and metribuzin provided better control performance than their isolated applications. This association provided greater residual control for Mucuna aterrima and Sorghum halepense and Rottboellia exaltata, This improved control 
efficiency can be attributed to physicochemical characteristics and weed control spectrum of each herbicide. providing a potential option for sugarcane fields with small amount of straw on the soil surface, as occurs, for instance, in line up straw and/or plant-cane systems.

\section{Conclusions}

Indaziflam herbicide presented a better performance in controlling monocotyledonous plants than eudicot plants. Applications on more substantial amounts of straw showed to be less effective than applications on lower amounts of straw. The herbicides amicarbazone and metribuzin presented adequate control of Mucuna aterrima despite having lower residual control. Metribuzin presented some residual control at different times of emergence. On the other hand, isoxaflutole showed long residual control of Sorghum halepense and Rottboellia exaltata, regardless of straw amounts.

The association of indaziflam + metribuzin, resulted in satisfactory results for Mucuna aterrima, Sorghum halepense, and Rottboellia exaltata, even for applications on different amounts of straw, probably due to the various emergence times.

\section{REFERENCES}

1. ALAM. 1974. Recomendaciones sobre unificación de los sistemas de evaluación en ensayos de control de malezas. Asociación Latinoamericana de Malezas. 35-38.

2. Alonso, D. G.; Koskinen, W. C.; Oliveira, R. S.; Constantin, J.; Mislankar, S. 2011. Sorption-desorption of indaziflam in selected agricultural soils. Journal of Agricultural and Food Chemistry. 59(24): 13096-13101.

3. Azania, C. A. M.; Rolim, J. C.; Casagrande, A. A.; Lavorenti, N. A.; Azania, A. A. P. M. 2006. Herbicide Selectivity. III - Herbicide Application at Initial and Late Postemergence of Sugarcane in Dry Season. Planta Daninha. 23(4): 683-691.

4. Barbosa, J. C.; Maldonado Jr, W. 2015. Experimentação Agronômica e AgroEstat-Sistema para Análises Estatísticas de Ensaios Agronômicos. Jaboticabal. Multipress. 396 p.

5. Ben, A. K. A. N.; Possamai, A. C. S.; Cardoso, W. S.; Ben, R.; Castro, E. B.; Mendes, K. F. 2015. Lixiviação e persistência de metribuzin por bioensaios. Scientia Plena. 11: 1-8.

6. Christoffoleti, P. J.; Ovejero, R. F. L.; Damin, V.; Carvalho, S. J. P. de; Nicolai, M. 2008. Comportamento dos herbicidas aplicados ao solo na cultura da cana-de-açúcar. Piracicaba. Escola Superior de Agricultura "Luiz de Queiroz". 90 p.

7. Concenço, G.; Machado, L. A. Z.; Ceccon, G. 2012. Espécies de Sorghum infestantes: importancia produtivos e manejo em sistemas. Embrapa. 1-9.

8. Concenço, G.; Filho, J. R. A. L.; Silva, C. J. da. 2017. O Aleiramento do Palhiço de Cana-de-Açúcar Agrava a Infestação de Plantas Daninhas. Embrapa. 3: 1-4.

9. Da Silva, P. V.; Monquero, P. A.; Silva, F. B.; Bevilaqua, N. C.; Malardo, M. R. 2015. Influence of sugarcane straw and sowing depth on the emergence of weed species. Planta Daninha. 33: 405-412.

10. Homer, I.; Prieto, M.; Diaz, V. 2020. Use of anti drift nozzles in control of perennial weeds in vineyard nurseries. Revista de la Facultad de Ciencias Agrarias. Universidad Nacional de Cuyo. Mendoza. Argentina. 52(2): 337-348.

11. Leal, M. R. L. V.; Galdos, M. V.; Scarpare, F. V.; Seabra, J. E. A.; Walter, A.; Oliveira, C. O. F. 2013. Sugarcane straw availability, quality, recovery and energy use: A literature review. Biomass and Bioenergy. 53: 11-19.

12. Lins, H. A.; Paes Barros Júnior, A.; Valadão Silva, D.; de Freitas Souza, M.; Moreira de Freitas, M. A.; Bezerra Soares, E.; Formiga Porto, M. A.; Campos de Mesquita, H.; Sarmento de Oliveira, F. 2020. Effectivity and selectivity of herbicides applied in pre-emergence in the sesame (Sesamum indicum L.) crop. Revista de la Facultad de Ciencias Agrarias. Universidad Nacional de Cuyo. Mendoza. Argentina. 52(2): 325-336.

13. Monquero, P. A.; Amaral, L. R.; Binha, D. P.; Silva, P. V.; Silva, A. C.; Martins, F. R. A. 2008. Mapas de infestação de plantas daninhas em diferentes sistemas de colheita da cana-de-açúcar. Planta Daninha. 26 (1): 47-55.

14. Monquero, P. A.; Hijano, N.; Orzari, I.; Dos Santos Sabbag, R.; Da Silva Hirata, A. C. 2012. Profundidade de semeadura, $\mathrm{pH}$, textura e manejo da cobertura do solo na emergência de plântulas de Rottboellia exaltata. Semina: Ciências Agrárias. 33: 2799-2812.

15. Possamai, A. C. S.; Inoue, M. H.; Mendes, K. F.; De Santana, D. C.; Ben, R.; Dos Santos, E. G. 2013. Potencial de lixiviação e efeito residual de amicarbazone em solos de texturas contrastantes. Semina: Ciências Agrárias, 34 (5): 2203-2210.

16. Sebastian, D. J.; Nissen, S. J.; Westra, P.; Shaner, D. L.; Butters, G. 2016. Influence of soil properties and soil moisture on the efficacy of indaziflam and flumioxazin on Kochia scoparia L. Pest Management Science. 73 (2): 444-451. 
17 . Silva, G. B. F.; Azania, C. A. M.; Novo, M. C. S. S.; Wutke, E. B.; Zera, F. S.; Azania, A. A. P. M. 2012. Tolerance of Mucuna species to herbicides used in sugarcane culture. Planta Daninha. 30(3): 589-597.

18. Silva, P. V. da; Monquero, P. A. 2013. Influência da palha no controle químico de plantas daninhas no sistema de Straw influence on chemical weed control in raw sugarcane system. Revista Brasileira de Herbicidas. 12(1): 94-103.

19. Rodrigues, B. N.; Almeida, F. S. 2018. 7̣ ed. Guia de Herbicidas. Londrina. Edição dos autores. 764 p.

\section{ACKNOWLEDGEMENTS}

We would like to thank the São Paulo Research Foundation (FAPESP) for the financing and support of this research (Process: 2015/14833-0). 